\title{
Demonstrating Value: School Library Media Centers Still Worth Their Keep
}

\author{
by Marilyn L. Shontz \\ "to ensure that students and staff are effective users of ideas and information." \\ (American Association of School Librarians and Association for Educational Communications \\ and Technology, Information Power [Chicago,IL:American Library Association],1988, 1.)
}

oday's school library media programs are charged with a mission that is at the heart of all learning and the foundation for worthwhile educational outcomes at all levels. As students and staff become effective users of ideas and information, they also become lifelong thinkers, readers, and learners. ${ }^{1}$ Interestingly, in 1961, the NEA Educational Policies Commission identified "the development of the ability to think" as the central purpose of education: "it must be a pervasive concern in the work of the school. Many agencies contribute to achieving educational objectives, but this particular objective will not generally be attained unless the school focuses on it."2

In fulfilling the library media program mission, the school library media professional as an information specialist provides physical and intellectual access to information resources in a variety of formats and learning levels. Students must be selectors, evaluators, interpreters, users, and communicators of ideas and information. The school library media program is the one unique place in the school where resources are available for this kind of learning activity to take place. The school library media specialist naturally also becomes an instructor and guide. The growing numbers of information resources in electronic or media formats, and the more traditional print materials, require different skills that must be fostered in students.

The school library media specialist also is challenged to serve as an instructional resource for teachers. The mission is not just that students, but that students AND staff are to be effective users of information and ideas. Individual teachers will be at different stages of becoming effective users, thus the school library media specialist works with them at whatever level is needed. In order to fulfill these three major roles and the library media program mission, today's school library media specialists are also in- sightful planners, preeminent managers, and creative, confident leaders of their programs, their schools, their districts, and their communities.

Our developing high technology schools exemplify the growing numbers of library media programs which are fulfilling their broad-based mission in the K-12 schools. These library media programs have online catalogs and circulation systems, provide access to CD-ROM information sources and searching, have fax machines, are members of interlibrary networks providing access to materials outside the school, use cable TV and satellite technology, have telephones, and provide microcomputer access for students and teachers. Moreover, their library media specialists work many hours per week with teachers in instructional planning. ${ }^{3}$

\section{School Library Media Program Costs}

So, what does this vision of the school library media program as integral to learning outcomes in our schools cost? For school library media programs to fulfill this mission, what are the costs to taxpayers? What resources must we commit? Citizens, who believe in and support a democratic way of life and, as taxpayers, support an educational system that ensures continuation of that way of life for future generations, have a right to know that their lawmakers and public educators are using allocated funds to reach this goal in the most effective ways possible.

A look at data about school library media programs presented in the latest series of School Library Journal ${ }^{4}$ reports covering the school year 199192 , provides interesting cost estimates. The ongoing purpose of this biennial series has been to collect and present information about school library media program expenditures for materials and resources. Although there are some non-materialsrelated expenses such as funds forcertain supplies, binding, and 
salaries for support staff that are not requested of the respondents, the results can be considered a reliable estimate of annual school library media program expenditures of local funds.

Data calculations ${ }^{5}$ in Table 1 show the estimated annual cost of school library media programs ${ }^{6}$ by grade and per capita levels. A typical elementary school represents an annual minimum investment of $\$ 40,000$ or $\$ 70.18$ per pupil. In contrast, a high-tech elementary school [Table 2], represents a typical annual minimum investment of $\$ 48,837$ or $\$ 76.79$ per pupil. ${ }^{7}$ Figures for middle/ junior high and high schools are included on both tables. placement costs per item, total costs can be calculated. Tables $3^{10}$ and $4^{11}$ show replacement costs calculated for books, audiovisual items, and microcomputer software by grade levels. Item replacement costs used in calculations were $\$ 21.50$ per book, $\$ 55.00$ per audiovisual item, and $\$ 66.00$ per microcomputer software program. ${ }^{12}$ No estimates for CD-ROM programs/equipment, audiovisual hardware, or microcomputer hardware are included. Library media collections can be seen to represent a school and community asset of $\$ 250,000$ (median), ranging from a low of $\$ 224,000$ to over $\$ 314,000$. Although high-tech school collections as reflected in Table 4 do have a greater overall value, the difference is not great. In this case, the exclusion of an approximate cost for CD-ROM programs could be a significant factor in underestimating the worth of hightech collections.

Knowing that our estimated annual cost of from $\$ 40,000$ to $\$ 54,000$ represents about one and one-half percent of the total national annual expenditure per pupil in public education, and that the estimated median replacement value of our collections is $\$ 250,000$, the question remains: is it worth it? Are the services provided worth the cost? Approaches too numerous to mention might be used to answer or, more accurately, attempt to answer, what is in essence a cost-benefit analysis problem. But failure to try this analysis leaves the system and its users without a viable alternative in addressing accountability. As a starting point, a look can be taken at the value that our public education system provides to society.
Elementary

Middle/Jr. high

High schools
ESTIMATED ANNUAL COST: HIGH TECH SLM PROGRAMS

\begin{tabular}{|c|c|c|c|} 
Median TME & Median Salary & $\begin{array}{c}\text { Total Annual } \\
\text { Cost }\end{array}$ & $\begin{array}{c}\text { Cost } \\
\text { Per Pupil }\end{array}$ \\
$\$ 122,550.00$ & $\$ 36,287.00$ & $\$ 48,837.00$ & $\$ 76.79$ \\
$\$ 14,127.00$ & $\$ 37,541.00$ & $\$ 51,668.00$ & $\$ 61.51$ \\
$\$ 16,050.00$ & $\$ 38,043.00$ & $\$ 54,093.00$ & $\$ 66.21$ \\
\hline
\end{tabular}

Table 3

\section{SLM COLLECTIONS: ESTIMATED REPLACEMENT COSTS}

cost of education to our communities, the National Center for Education Statistics (NCES) reports an estimated per-pupil expenditure for 1993-94 of $\$ 5,193$ for all grade levels. ${ }^{8}$ When calculated, specific expenditures for school library media programs represent about one and onehalf percent of that total. The per-pupil expenditure reported for North Carolina is $\$ 4,276.9$

Another possible way of estimating the investment or cost represented by school library media programs is to calculate the value of the internal collection. Using the SLJ survey collection size estimates and approximate re- \begin{tabular}{|l}
\hline \\
\hline$E$ \\
$M$ \\
$H$
\end{tabular}

\begin{tabular}{|l|c|c|c|c|}
\cline { 2 - 5 } & Median Books & MedianAV & $\begin{array}{c}\text { Median Micro } \\
\text { Software }\end{array}$ & Total \\
\hline Elementary & $\$ 186,985.50$ & $\$ 32,725.00$ & $\$ 4,686.00$ & $\$ 224,396.50$ \\
Middle/Jr. high & $\$ 215,000.00$ & $\$ 26,015.00$ & $\$ 2,244.00$ & $\$ 243,259.00$ \\
High schools & $\$ 258,000.00$ & $\$ 27,500.00$ & $\$ 990.00$ & $\$ 286,490.00$ \\
\hline
\end{tabular}

Table 4

HIGH-TECH SLM COLLECTIONS: ESTIMATED REPLACEMENT COSTS

\begin{tabular}{|l|c|c|c|c|}
\cline { 2 - 5 } & Median Books & Median AV & $\begin{array}{c}\text { Median Micro } \\
\text { Software }\end{array}$ & Total \\
\hline Elementary & $\$ 191,350.00$ & $\$ 27,500.00$ & $\$ 5,280.00$ & $\$ 224,130.00$ \\
Middle//r. high & $\$ 215,000.00$ & $\$ 22,935.00$ & $\$ 3,366.00$ & $\$ 241,301.00$ \\
High schools & $\$ 279,500.00$ & $\$ 33,000.00$ & $\$ 1,518.00$ & $\$ 314,018.00$ \\
\hline
\end{tabular}




\section{Costs of At-Risk Students and Dropouts}

Everyone has heard it, especially those of us in the information profession. American society is beset with serious social problems - crime, illiteracy, poverty, substance abuse, family disintegration. Human misery costs uncountable billions in both tax dollars and donated time, money, and materials. Our awareness of the drain on our static or diminishing resources grows more acute. We seek solutions. Specific responses have included crackdowns on crime - to get the criminals off the street and into prisons - and the provision of monetary support to people in crisis in the form of unemployment benefits and welfare. These responses work: criminals are going to jail in record numbers and people are receiving enough money to get by. But more criminals come along, and more people become victims in categories which require direct governmental financial support.

While almost no one advocates abandoning these programs, a perhaps less costly and workable solution is now clearly within our reach. We can emphasize prevention as a cure. We must nurture, support, and cherish our children, each and every one. They are society's most vulnerable members. Because they are the youngest, they are without political power; and, in the past, have been without advocates, especially advocates with political power. Paradoxically, they also provide us with the greatest and most promising opportunity for reducing the cost of social ills. If public education can reduce risk to children, our society will benefit monetarily and, one could certainly add, morally. If good school library media programs contribute to schools that in turn reduce the numbers of at-risk children, what appears to be a relatively small investment is most certainly worth it.

First we need to review some of what we know about children at risk:

- From twenty to forty percent of our students can be categorized as at-risk ${ }^{13}$

- Twenty-five percent of all youth face serious risk of not reaching productive adulthood; an additional twenty-five percent are at moderate risk ${ }^{14}$

- Youth living in rural or urban poverty are at the highest risk ${ }^{15}$

- In 1991 only twenty-two percent of three- and fouryear-olds from low income families were enrolled in pre-kindergarten programs, a decrease from thirty percent in $1990^{16}$

- Twenty-one to twenty-three percent of adults function at the lowest level of literacy, half of these (twenty to twenty-two million) live in poverty 17

- High school completion rate for nineteen- to twentyyear-olds is ninety percent for white students, eighty percent for black students, and sixty percent for Hispanics. The resulting national dropout rate of from twenty to twenty-five percent has remained constant in the late 1980 s and early 1990 s $^{18}$

- Forty percent of white and twenty-five percent of black high school dropouts find employment, as compared to seventy-five percent of white and thirtyfive percent of black high school students who do not go on to college (1991) ${ }^{19}$

- Thirty-three percent of high school sophomores who aspire to attain no more than a high school diploma, score in the two lowest test performance quartiles $(1990)^{20}$
- Fifty-two percent of non-white sophomores have no education plans past high school (1990)21

- Twenty-one percent of high school sophomores who have no education plans past high school are from the lowest socio-economic group (1990) 22

- Twenty-one percent of all children and fifty-nine percent of all children living in a household with a single mother live in poverty 23

- While the number of arrests of people ages fourteen to thirty-four are increasing, arrests in the fourteen- to seventeen-year-old group increased by fifteen percent from 1989 to $1990^{24}$

- Seventy percent of the prison population perform at the lowest literacy levels 25

And in North Carolina: 26

- There has been a seven percent rise in juvenile crime, twice the national average

- Twenty percent of our children under the age of five live in poverty

- Eighty percent of prison inmates grew up in poverty

While specific data on the cost to society of school dropouts and at-risk children from poverty-level homes are not readily available or easily produced, costs associated with some of the results of poverty and low education levels are available. Since a high percentage of young people who live in poverty and drop out of school wind up in our criminal justice system, lowering the costs for that system and its services can be related directly to school activities and success.

First, from the perspective of juveniles and adults in the criminal justice system, the national average annual (1989-90) operation expenditure per adult inmate in our criminal justice system was $\$ 15,496.27$ The cost per inmate in North Carolina was $\$ 18,486.28$ The average national annual per capita cost to keep one juvenile in custody was approximately $\$ 31,015(1989) .29$ As a comparison: the cost for keeping a student in school for one year was $\$ 5,193$, so to keep a tenth-grade student in school until graduation would cost on the average $\$ 10,386$. To deal with that same tenth-grader as a juvenile offender will cost $\$ 62,030$ for two years. A five-year prison sentence for the same individual in an adult facility will cost $\$ 92,430$ in North Carolina. Clearly, keeping potential teenage dropouts in school for graduation makes good economic sense.

Another view of the costs can be taken from the other end of the school curriculum. We know that a crucial factor in determining whether young children are at-risk is their level of readiness to learn upon entering kindergarten. Children who start behind are more likely to stay behind. Using estimates from a 1990 United States Department of Education-funded study, preschool child care is provided to parents at an average hourly fee of from $\$ 1.19$ in public school programs to a high of $\$ 1.73$ in independent nonprofit child care centers. ${ }^{30}$ For a typical 50 -hour-week, 52-week-year which would be needed by a working mother, these costs total from $\$ 59.50$ to $\$ 86.50$ per week, or $\$ 3,094$ to $\$ 4,498$ per year. Five years of preschool care for one child before starting kindergarten would cost $\$ 19,000$, or about as much as it costs to keep one adult prisoner incarcerated for one year.

Another hypothetical example provides more interesting comparisons. If we use the estimate that twenty percent of the children in any school are at-risk, an elementary school of 800 students today can have 160 at-risk students. Providing preschool programs for these children when they are three and four 
years old, so they will begin school ready to learn and succeed, would cost about $\$ 7,592$ each for two years. For all 160 children, the cost would be $\$ 1,214,720$. Keeping those same 160 teenagers in juvenile custody for two years, however, would cost $\$ 9,600,000$. A five-year prison sentence for each juvenile offender in North Carolina would cost taxpayers $\$ 14,788,800$. While it is unlikely that all 160 at-risk children would spend five years in prison, the cost to society if even half of them do is staggering. And, while we will probably never completely eliminate crime and poverty, it is clear that our educational system has the power to reduce, through prevention, the number of children at-risk as well as increasing the number of young people who graduate and successfully enter society as contributing members and lifelong learners.

\section{Library Media Program Value to Successful Schools}

The question stated earlier about the value of library media programs has become a little clearer. Schools that have lower dropout and at-risk student rates are cost effective models for society. But, do we know if good school library media programs contribute to the effective school model? The answer is yes. Over a period of thirty years, evidence has been accumulating that library media programs contribute significantly to effectiveschools and successful students.

Active and effective school library media programs can and do help create effective schools. Groover, Marchant, Didier, and Haycock have each analyzed previous research in school library media services and presented conclusions that document the contributions of the school library media program to student outcomes. ${ }^{31}$ Three of the reported studies are especially interesting in light of today's emphasis on accountability. They represent three very different but promising approaches to the costbenefit analysis problem and solution.

The earliest of the three studies took place in the Calgary (Canada) school district from 1977 to 1979 . The Calgary Board of Education wanted to know, "When dollars are devoted to school library services, is there a corresponding value for students?"32 Rather than comparing schools with/without school libraries as Gaver had done earlier, 33 they used Gaver's "Inventory of Library Services" to profile the numbers and types of services provided in the sixtyfive selected elementary and high schools. ${ }^{34}$ Locally developed attitude scales and skills tests also were used as measures.

As a result of their study, Calgary was able to identify a basic core of services provided to all students in all schools termed "Baseline Library Services." 35 The presence of a higher number of these services correlated with the presence of a full time teacherlibrarian and an adequate budget. ${ }^{36}$ In the high schools, there was a positive correlation between improved student skills and positive attitudes and teacher-librarians' direct involvement in teacher consultation activities. ${ }^{37}$ Elementary schools revealed a strong positive effect on student attitudes when teacher-librarians jointly planned with teachers, and the library media program was integrated with classroom activities and instruction. ${ }^{38}$
As a case study, the Calgary survey represents a workable model for the profession. Since it was limited to selected schools in one geographic area, the results could not be generalized to other schools and districts. However, the researchers felt that as a result of the study, they had demonstrated that in their school district those schools that were providing high levels of the baseline services were making definite, positive contributions to student outcomes - attitudes and skills - and that school libraries were "definitely worth their keep." 39

A second approach was described and reported by Loertscher, Ho, and Bowie in 1987.40 Their purpose was to describe library media services offered in elementary schools and to affirm, if possible, that exemplary schools have exemplary library media programs. Using 209 United States Department of Education nationally recognized elementary schools (1986), the researchers looked at staffing, services to students, services to teachers, and resources/operations. One of their major conclusions was that excellent library media programs in excellent schools have a minimum staff of one full time professional and one clerk. 41

As a result of this research, the profession can better describe what good school library media programs do and what they contribute to excellent elementary school programs. Conclusions drawn by the researchers about the library media programs included: for maximum impact on school outcomes, elementary library media programs should be staffed by a full-time library media specialist and a clerk and should operate on a flexible schedule; their programs should emphasize literature-rich activities and promote enjoyment of reading, a partnership with teachers in developing instruction, individual assistance to learners, creative use of new materials/ technology, and integration of information skills instruction into curricular areas. 42

The last and most recent of the studies provides a third approach and a new viewpoint. Using a representative sample $(\mathrm{n}=221)$ of all Colorado Public Schools, researchers collected data on school variables, community variables, library media program variables, and test score results by grade level from the 1988-89 school year. 43 The researchers wanted to document the relationship, if any, between library media center expenditures and student achievement; the characteristics of library media programs that contribute to higher student achievement; and whether collaboration between the library media specialists and teachers on instruction contributes to student achievement. ${ }^{44}$ The use of readily available test score data (ITBS and TAP) by selected grade levels was analyzed for statistically significant relationships with (1) selected community factors: high school graduation rate, poverty level, family income and size, and urban-rural designation; (2) selected school variables: pupil/teacher ratio, education level of teachers, teachers' years of experience, teachers' salaries, and expenditures per pupil; (3) selected library media program variables: staff, instructional role, collection size, circulation, availability, and use of microcomputers, and amount of information skill instruction. ${ }^{45}$

In answer to their study questions, researchers found that: 
(1) students at schools with better funded library media programs tended to achieve higher average test scores regardless of socioeconomic level or educational level of the community; (2) the size of the library media program total staff and the size and variety of its collection contribute to the ability of the library media program to influence student achievement; and (3) students whose library media specialists collaborated with teachers in planning instruction tended to achieve higher test scores. 46

\section{Still Needed ...}

We now know, and have evidence that shows, that good school library media programs - those with adequate staff, collections, and services - contribute to student success and learning in our schools and that successful, effective schools can save money. But, what factors are still serving as barriers to providing all students with good school library media programs? There are three that are easily recognizable from the current literature.

As noted earlier, our collections represent a major investment for our communities and our nation. Collection surveys completed recently in several states show the increasing age of materials and, therefore, their declining usefulness for today's information-age students. The results of some of these surveys have been presented as part of the ESEA initiative in Congress.

The second barrier can be found in the documentation of staffing cutbacks. While each study of effective library media programs demonstrates the need for one full time professional and one clerk as a minimum staff level, school districts continue to see library media positions as ones that are expendable. The number of school library media positions continues to decline.

The third barrier is that of research. While it is true that there are numerous studies related to what makes an effective school library media program, the fact that it is spread out over thirty years makes interpreting the results for today's technologycentered programs problematic. Many of the older models are excellent but need to be replicated in the current setting. Those more current studies such as the one in Colorado need to be replicated in other geographic areas.

But an even more basic problem stands in the way of quality research. Individual school library media specialists must begin to collect data in an organized, uniform fashion. The profession must agree on standardized research methods and data collection techniques in order to enable library media specialists to collect and present data that can be used as measures or benchmarks for program improvement.

\section{References}

${ }^{1}$ American Association of School Librarians and Association for Educational Communications and Technology, Information
Power (Chicago, Il: American Library Association, 1988), 15.

${ }^{2}$ Educational Policies Commission, The Central Purpose of American Education (Washington, D.C.: National Education Association, 1961).

${ }^{3}$ Marilyn L. Miller and Marilyn L. Shontz, "Inside High-Tech School Library Media Programs," School Library Journal 40:4 (April 1994): 24-29.

${ }^{4}$ Marilyn L. Miller and Marilyn L.Shontz, "Expenditures for Resources in School Library Media Centers, FY 1991-92" School Library Journal 39:10 (October 1993):26-36.

5 Calculations are based on results reported Tables 9 and 14. Miller and Shontz, "Expenditures for Resources in School Library Media Centers, FY 1991-92," 30,34.

$6 \mathrm{TME}$ is the total of median expenditures per school from local funds for materials/resources of all types, audiovisual equipment, microcomputer hardware, online services, rentals, leasing, and maintenance. Median salary is for one full time certified school library media specialist at the specified grade level.

7 Calculations are based on results reported in Tables 3 and 7 . Miller and Shontz, "Inside High-Tech School Library Media Programs," 25,28.

${ }^{8}$ National Center for Education Statistics, Public Elementary and Secondary Education Statistics: School Year 1993-94 (Washington, D.C.: Office of Educational Research and Improvement, 1993), 8.

9 Ibid.

10 Calculations are based on results reported in Table 9. Miller and Shontz, "Expenditures for Resources in School Library Media Centers, FY 1991-92," 30.

11 Calculations are based on results reported in Table 7. Miller and Shontz, "Inside High-TechSchoolLibraryMedia Programs," 29.

12 Mean cost of one book is based on average of prices for juvenile, adult books, and paperback books as reported in The Bowker Annual Library and Book Trade Almanac, 38th ed.(New Providence, N.J.: Reed Publishing, 1993). Mean cost of one audiovisual item is based on typical per item prices reported in Media Review Digest,vol. 23,(Ann Arbor, Mich.: Pierian Press, 1993). Mean cost of one computer software program is based on typical per item prices reported in The Latest and Best of TESS; The Educational Software Selector (Hampton Bays, N.Y.:EPIE, 1991).

13 "Improving Possibilities for Students Placed at Risk." OERI Bulletin (Winter 1994): 3.

${ }^{14}$ Carnegie Council on Adolescent Development, A Matter of Time; Risk and Opportunity in the Nonschool Hours (New York: Carnegie Corporation of New York, 1992), 19.

15 Ibid.

16 National Center for Education Statistics, The Pocket Condition of Education 1993 (Washington, D.C.: Office of Educational Research and Improvement, 1993), 2.

17 "How Literate Are American Adults?" OERI Bulletin (Fall 1993):1,4.

18 National Center for Education Statistics. The Pocket Condition of Education 1992 (Washington, D.C.: Office of Educational Research and Improvement, 1992), 1.

19 NCES, The Pocket Condition of Education 1993, 4.

20 Thomas D.Snyder and Carol Sue Fromboluti, Youth Indicators 1993; Trends in Well-Being of American Youth (National Center 
for Education Statistics, Office of Educational Research and Improvement, 1993), 136.

21 Ibid.

22 Ibid.

23 Ibid., 48.

24 Youth Indicators, 131.

25 "How Literate Are American Adults?", 1.

26 "Smart Start," Tar Heel Libraries 17:2 (March/April 1994):2.

27 Michael J. Hindelang Criminal Justice Research Center, Sourcebook of Criminal Justice Statistics 1992 (Washington, D.C.:

U.S. Department of Justice, 1992), 13.

28 Ibid.

29 Ibid., 584.

30 Mathematica Policy Research, Inc., A Profile of Child Care Settings: Early Education and Care in 1990; Executive Summary (Washington, D.C.: U.S. Department of Education, 1991), 4.

31 Robert Groover, "Library Media Programming and Learning: A Summary of Research" CMELA Journal 3 (Spring 1980):29-34; Maurice P. Marchant, et al., "Research Into Learning Resulting From Quality School Library Media Service" School Library Journal" (April 1984): 20-22; Elaine K. Didier, Research on the Impact of School Library Media Programs on Student Achievement - Implications for Professionals" in School Library Media Annual Vol. 2, 1984 edited by Shirley Aaron and Pat Scales (Littleton, CO: Libraries Unlimited, 1984), 343-61; Ken Haycock, What Works: Research About Teaching and Learning Through the School's Library Resource Centre (Seattle: Rockland Press, 1992).

32 Yvonne Hodges, "Resource Center Programs Are Here to Stay...The Proof is in the Evaluation" School Libraries in Canada 3 (Winter 1983):20.

${ }^{33}$ Mary Virginia Gaver, Effectiveness of Centralized Library

\section{Tired of making} "permanent loans?"

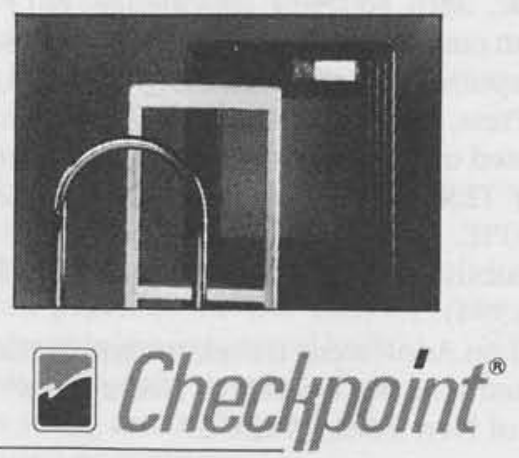

Tomorrow's Technology for Today's Libraries ${ }^{\mathrm{TM}}$

550 Grove Road • P.O. Box 188 - Thorofare, New Jersey 08086 (800) 257-5540 - TELEX: 84-5396 - FAX: (609) 848-0937

Ralph M. Davis, Sales Representative

P.O. Box 144

Rockingham, NC 28379

1-800-545-2714
Service in Elementary Schools (New Brunswick, N.J.: Rutgers University Press, 1963); Mary Virginia Gaver, Services of Secondary School Media Centers (Chicago: American Library Association, 1971).

34 Hodges, "Resource Center Programs Are Here to Stay," 20.

35 Bev Anderson, "School Libraries - Definitely Worth Their Keep" Emergency Librarian 10:5 (May/June 1983):7

36 Ibid., 9.

37 Hodges, "Resource Center Programs Are Here to Stay," 24.

38 Anderson, "School Libraries - Definitely Worth Their Keep,"9.

39 Ibid.

40 David V. Loertscher, May Lein Ho, and Melvin M. Bowie, "Exemplary Elementary Schools and Their Library Media Centers: A Research Report" School Library Media Quarterly 15 (Spring 1987): 147.

41 Ibid., 152.

42 Ibid., 153.

43 Keith Curry Lance, Lynda Welborn, and Christine HamiltonPennell, The Impact of School Library Media Centers on Academic Achievement (Castle Rock, Colo.: Hi Willow Research and Publishing, 1993), 2.

44 Ibid.

45 Ibid., 18-21.

46 Ibid., 93.

\section{About THE AUthors}

\section{Kem B. Ellis}

Education: B.A., High Point University; M.L.S., UNC-Greensboro Position: Director, High Point Public Library

\section{Gary Harden}

Education: B.A. Concord College; M.L.S., N.C. Central University

Position: Systems Librarian, State Library of North Carolina

\section{Dwight McInvaill}

Education: B. A., Presbyterian College; M.L.S. UNC-Chapel Hill

Position: Head of Adult Services, Kinston/Lenoir County Public Library

Edward T. Shearin, Jr.

Education: A.A., Chowan College; B.A., NC Wesleyan College; M.L.S., East Carolina University; Ed.D., NCState University

Position: Director, Library/LRC Carteret Community College

\section{Marilyn Shontz}

Education: B.A., Heidelberg College; M.L.S., Case-Western Reserve University; Ph.D., Florida State University

Position: Associate Professor, Department of Library and Information Studies, UNC-Greensboro

\section{Martha M. Smith}

Education: B.A., Duke University; M. Div., Duke Divinity School M.S.L.S., UNC-Chapel Hill; Ph.D., Duke University

Position: Head Librarian, St. Mary's College

\section{Joel Sigmon}

Education: B. M., Florida State University; M.M., Florida State University; M.L.S., N.C. Central University

Position: Head, Government and Business Services Branch, State Library of North Carolina

\section{John T. Welch}

Education: B. M., Memphis State University; M.S.L.S., Catholic University of America

Position: Assistant State Librarian, State Library of North Carolina 


\section{From North Carolina News \\ to National \\ Issues to \\ International Affairs}

\section{NEWSBANK HAS IT ALL ON COMPACT DISC}

\section{THe NewKSEOBSERVVER}

FULL TEXT ON CD-ROM

Coverage of local, regional, state and U.S./world news from one of North Carolina's leading newspapers.

\section{NEWSBANK}

Full-text coverage of today's key issues and events from over 40 major U.S. newspapers and wire sevices worldwide.

Together, these CD-ROM resources give you instant access to news from within the state, across the nation and around the world.

- MONTHLY UPDATES keep you current

- UNIFORM SEARCH SOFTWARE makes multidatabase research quick and eosy

- BACKFILES enable you to build extensive news archives on CD-ROM

The Raleigh News \& Observer coverage ranges from feature articles to locally-written columns and editorials, while CD NewsBank provides articles chosen by information specialists based on research value and in-depth reporting.

Call NewsBank TODAY to learn more about these complementary databases:

\section{$1-800-762-8182$}

Be sure to osk about the SPECIAL OFFER on current year subscriptions and backfiles.

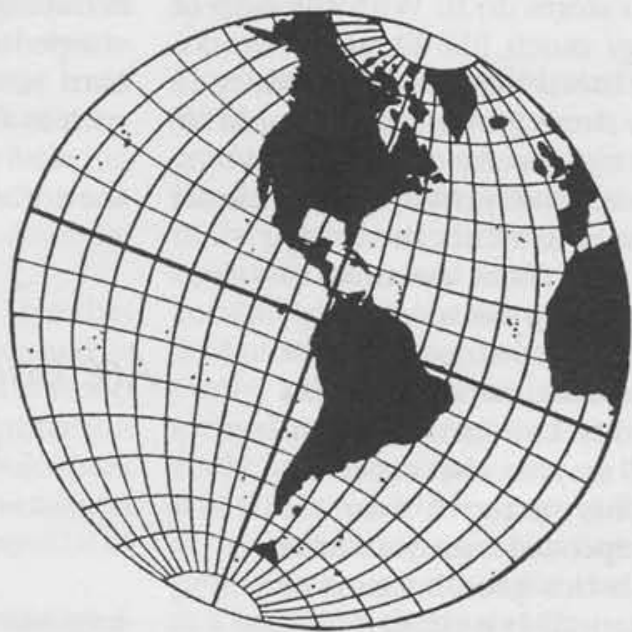

